\title{
Drug-fuelled counterculture
}

\author{
Albion Dreaming: A Popular History of LSD \\ in Britain \\ by Andy Roberts \\ Marshall Cavendish: 2008. 288 pp. £18.99
}

LSD - lysergic acid diethylamide - is an evocative acronym: it strikes a rational fear into governments and an irrational one into the media. Those who have taken the drug are in awe of its transformative power; to those who have not, it is a dangerous unknown.

Since LSD was invented by Swiss chemist Albert Hofmann, who referred to it as his "problem child", it has been a drug in search of a use. LSD is now inching its way back onto research agendas in the United States and Europe.

Albion Dreaming is a timely book, especially given Hofmann's death this year. It examines how a compound viewed by some as having unmatched potential for positively transforming society through individual enlightenment, instead fuelled a decades-long counterculture, which was eventually suppressed. With investigative zeal, Andy Roberts charts the highs and lows of LSD's relationship with the anarchists and intellectuals of 1950s, 1960s and 1970s Britain, and takes the reader on a magical mystery tour through the cultural changes catalysed by the most potent chemical known to humankind.

The British government was at first intrigued by LSD's potential. When the compound reached its shores in 1952, the medical and military establishments were keen to investigate and exploit the drug in psychotherapy and as a battlefield weapon, respectively, as was the Central Intelligence Agency across the Atlantic.

The United States is rightly considered to be the cheerleader of LSD-fuelled counterculture, but the author convincingly demonstrates that Britain had a strong supporting role. The term 'psychedelic' was invented in a creative wordplay between two Englishmen, the writer Aldous Huxley and his doctor friend Humphrey Osmond, who first gave him mescaline. Huxley's "To make this trivial word sublime, take half a gramme of phanerothyme [soulvisible]", was topped by Osmond's "To fathom hell, or soar angelic, take a pinch of psychedelic [mind-manifesting]."

It was a Briton too, Michael Hollingshead, who turned Harvard psychologist Timothy Leary on to LSD, after which Leary morphed into a self-styled psychedelic guru and urged the US youth to "Turn on, tune in, drop out", which they did in their millions.

Much has been written about Leary and his compatriots, but Albion Dreaming retains a gritty UK perspective. From the stillsecret experiments conducted at Britain's military research establishment at Porton Down, to Ronald Sandison, a doctor who opened the world's first specialized LSD psychotherapy unit at Powick Hospital in Worcestershire in 1952, the author packs the pages with a riotous selection of wellsourced anecdotes. Actor Sean Connery sampled LSD from the psy-

chiatrist's couch and his therapist demanded a fine single-malt whisky as part payment. The BBC's laudable - or is that laughable? — attempts to filter out 'drug-inspired' lyrics on radio led to a ban on The Beatles' song A Day in the Life, but Lucy in the Sky with Diamonds slipped through the net. Corrupt Drug Squad officers paid informants with LSD that had been seized in earlier raids, until the wellorganized Operation Julie smashed a major international manufacturing ring later in the 1970s, when up to half of the world's illicit LSD was made in Britain.

Although Roberts does not match the gripping narrative of Jay Stevens' Storming Heaven:
LSD and the American Dream (Atlantic Monthly Press, 1987), he spins a good yarn, distancing rumours such as Francis Crick's links to LSD from established fact. He found no proof to back the claim that Crick took LSD and saw the double helix in his visions. Conspiracy theories, namely allegations of the media's complicity with the police or the secret intelligence services, are also maturely circumvented.

The book could have included more about the scientific applications of LSD. Thousands of papers in the 1950s and 1960s suggested that LSD could be used as a treatment for conditions ranging from depression to alcoholism the founder of Alcoholics Anonymous was transformed by an LSD trip - but Roberts writes a popular history, not a scholarly one. Albion Dreaming provides the fullest account yet of recent legal battles in the United Kingdom that have been resurrected by those given LSD without consent. Soldiers who claimed they were used as guinea pigs were offered $£ 10,000$ (US $\$ 18,000$ ) each, and nearly 50 patients claiming to have had hallucinations, flashbacks, paranoia or chronic anxiety from LSD-assisted psychotherapy gained 20 times as much compensation.

The street-level perspective of the book works, but an over-reliance on the exploits of individuals leads to a lack of deeper insights. The concluding pages are wasted on an intelligent but irrelevant argument for the legalization of drugs, yet I wanted to know from the author why research on LSD has yet to resume in the United Kingdom, or why the psychedelic-powered revolutions did not take off across the world. Consequently, Albion Dreaming is an enjoyable journey but leaves the reader with more questions than answers - much like the LSD trip itself.

Arran Frood is a science writer based in the United Kingdom.

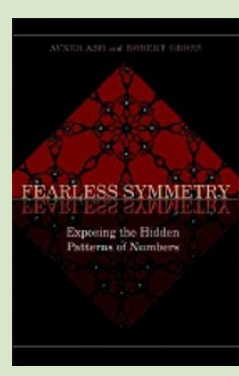

Fearless Symmetry: Exposing the Hidden Patterns of Numbers by Avner Ash and Robert Gross (Princeton Univ. Press, \$18.95) This book attempts to explain complex maths in an interesting way. Reviewing the hardback edition, Timothy Gowers wrote: "The authors are to be admired for taking a very difficult topic and making it, if not fully accessible, then certainly more accessible than it was before." (Nature 446, 26; 2007).

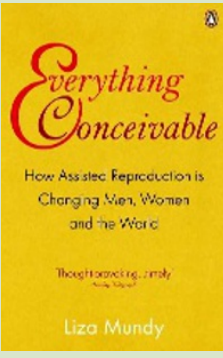

Everything Conceivable: How Assisted Reproduction is Changing Men, Women and the World

by Liza Mundy (Penguin, $€ 9.99$ )

Mundy looks at the consequences of the "reproductive revolution" in science that is changing who reproduces and how. She covers changes in society and technology, talking to physicians, scientists, parents and campaigners. 